\begin{tabular}{c} 
Journal of Political Science \\
(A Peer-Reviewed, Open Access Journal and Indexed in NepJOL) \\
ISSN 2362-1273 (Print); ISSN 2773-8132 (Online) \\
Volume 21, Special Issue, August 2021 \\
http://ejournals.pncampus.edu.np/ejournals/jps/ \\
Published by \\
Department of Political Science, Prithvi Narayan Campus, TU, Pokhara, Nepal \\
Email: polsc@ pncampus.edu.np; URL: $\underline{\text { www.pncampus.edu.np }}$ \\
\hline
\end{tabular}

\title{
Satisfaction Level of Old Age Allowance Receiving Elderly People in Kushma Municipality
}

\author{
Vijay Aryal* \\ Bhanu Bhakta Paudel ${ }^{*}$ \\ *Department of Population Studies, Prithvi Narayan Campus, Pokhara \\ ${ }^{* *}$ Pokhara University, Lekhnath
}

Corresponding Author: Vijay Aryal, Email: vijayaryal@ pncampus.edu.np

DOI: https://doi.org/10.3126/jps.v21i1.39290

Copyright 2021@ The Publisher and Author/s. The journal is licensed under a Creative Commons Attribution-ShareAlike 4.0 International License.

\section{(c) (i) ()}

Submitted 12 July 2021; Reviewed 15 July 2021; Accepted 28 July 2021; Published 20 Aug. 2021

\begin{abstract}
This paper discusses the contribution and effectiveness of old age allowance among the elderly people and also comes up with the factors associated with the satisfaction level of old age allowance. A cross sectional descriptive study was carried out among 136 elderly people receiving old age allowance in Kushma Municipality, Parbat. The information was collected from people aged 60 years and above through interviews using semi-structured questionnaires. The blend of qualitative and quantitative data was employed for the study. The majority of the elderly population was in the age group of 70-75 years with 68 percent elderly people illiterate. The result shows a significant association of the level of satisfaction of the allowances received with the physical infrastructure and socio-economic development regardless of age, gender and caste/ethnicity. This gives an impetus for making policies and programmes for the elderly in order for them to live with happiness and satisfaction.
\end{abstract}

Keywords: Ageing, elderly people, old age allowance, livelihood

\section{Introduction}

Ageing is a biological change that leads to weakening of physical and mental wellbeing. Ageing is associated with the health and other symptoms of later human life generally 


\section{Satisfaction Level of Old Age Allowance Receiving Elderly People}

referred to as 'geriatric syndromes' (WHO, 2018). In general, aging is a normal growth process, beginning from conception onwards. During the lifetime, various changes related to aging occur which alters the person's ability to function in his environment. An individual doesn't simply get old, as this is a long process that depends on heredity, diet, mental attitude, environment, and standard of living (Wallace, 1997). The population of senior citizens aged 60 years and above is over 2.1 million, which is almost $8 \%$ of the entire population (NPC, 2012). The universal entitlement in Nepal has ensured that over $80 \%$ of old-age individuals receive pensions (Babajanian, 2013). Old age is the natural phenomenon of the human life cycle. Among the various stages of human life, old age is the last stage. Most people above 60 years of age are considered 'old'. Those who are 60 years and above makeup the elderly section of any population (WHO, 2002). An increasing population of ageing has become a global issue and has emerged many new challenges to meet the increasing demands of the elderly people (Shrestha \& Satyal, 2003). Its pace is anticipated to be surprisingly rapid as mortality continues to decline and life expectancy keeps on increasing (Subedi, 1996).

As the population aged 65 and over is expected to increase in all regions of the world, the global figure of 9.3 percent in 2020 is projected to reach nearly 16.0 percent in the year 2050 (UNDESA/PD, 2020). In Nepal, with similar trend, there have been 1.5 million elderly inhabitants in 2001 and 2.1 million elderly inhabitants in 2011 that covered $6.5 \%$ and $8.14 \%$, respectively, of the country's total population in those 2 years (Shrestha, 2012). During the year 1991-2001, the annual elderly population growth rate of Nepal was 3.39\% which is higher than an annual population growth rate of $2.3 \%$ (CBS, 2012). Senior citizens have increased over the years and so does the number of the recipients of the social security allowances. This is creating pressure on the government's limited budget (Limbu, 2012). However, ageing is not a challenge in one country but in the whole world as it causes social and economic changes in every country. Gradually, the number of elderly people is increasing worldwide due to better facilities and advanced technologies. Also, the worldwide declines in the fertility rate and increase in life expectancy have increased the gradual ageing of the world's population (Yadav, 2012). As aging has been considered one of the most important demographic phenomena that the older people are increasing in almost the entire world, the combined effect of lowered fertility and improved health and longevity has generated growing numbers and the proportion of older population throughout the world. Both the developed and developing countries of the world are experiencing population aging and there is growing concern about population aging in the world (UNFPA, 2012).

Human Needs Theory by Maslow $(1943,1954)$ suggests a hierarchy that initially requires fulfillment of physiologic needs, followed by safety and security, then love/belonging, selfesteem, and finally self-actualization needs. However, some flexibility when understanding the hierarchy has relevancy for nurturing as well as providing proper care for adults in need of detailed information (Grossman and Lange, 2006).

The Senior Citizens Act 2063 (2006) of Nepal defines elderly people as those people who are aged 60 and above. However, there is a system of retirement age according to the profession in Nepal. The retirement age for the general administration group is 58 years, and 60 years for health service sectors. The retirement age in judiciary and University services is at 63 years and 65 years for the chief justice and the other members of the constitutional service. However, there is no specified retirement age in some sectors such as agriculture, politics and social service in Nepal. 


\section{Satisfaction Level of Old Age Allowance Receiving Elderly People}

In Bangladesh, the old age allowance program has obtained enormous significance to the country's poor older population. Such allowance helped them in gathering their basic needs, uplifting their status, and improving their psychological well being. Almost all the beneficiaries that belonged to poor households spent the money received on food and health care. However, they stated that this program was insufficient to cover all poor people of that age group (Begum and Wesumperuma, 2012).

Old Age Allowance is the main source of income of the elderly and this money is used for multiple purposes like foods and clothing and health related expenditure. The Old Age Allowance seeks to deal with the vulnerability of older people related to an explicit stage of a life cycle that creates it difficult to earn stable and reliable income, reducing old-age poverty and insecurity. Social security makes a crucial contribution in setting up greater social justice and peace. The state sponsored social security system is promoted because of the weakening of the extended family system, which used to provide economic and social security to the family members. Social security is a challenging issue in Nepal (Badal, 2005). However, the majority of the elderly people claimed that the elderly allowance that is being provided by the government is not properly received and is quite irregular (Bhatta, 2009) and insufficient (Malakar \& Chalise, 2018).

Among the elderly people, there is a prevalence of psychiatric morbidities such as stress prone and mood disorders (Khattri et al., 2020), 'depressive disorder' (Thapa et al., 2014) and various forms of retinal disorders, which increase with ageing (Thapa et al., 2020). The occurrence of health complications among the elderly people may cause dissatisfaction towards life. The status of proper nutrition and mental health has positive association with life satisfaction as well (Ghimire et al., 2018). The elderly people also have insufficient health services and facilities in many parts of the country. Kshetri and Smith (2011) found that the majority of the elderly had pain on joints with swelling and back pain among others, the problems increased with ageing. However, the unmet needs for those health problems among the elderly revealed a positive association with increase in age and more among women as compared to women of similar age groups. Due to the increasing trends of nuclear families in the urban areas, the feeling of loneliness is higher among urban dwellers as compared to the rural settings although the elderly people live with their married children (Kshetri et al., 2012).

At times, elderly people have to face social and financial obscurities. The traditional joint family system is slowly being replaced by the nuclear family in urban areas. The caring of elderly population is a major problem. Because of this trend of nuclear families, the older members of the family are being isolated. There is modification in the cultural norms and traditional family support systems for elderly that have placed them under substantial strain (Poudel, 2005).

Maintaining social status is also very important for the elderly people, especially to those, who were socially active before. So, to be associated with social activities along with their peers, family support and some forms of pension schemes have a positive impact on their lives (Gupta et al., 2016). Also, the satisfaction level of elderly people is associated with family relationship and the use of the allowance is remain them attached with their family and society (Dhungana et al., 2020). To meet the financial obligations at least for their livelihood, there needs to have the provision of financial assistance to the needy ones. 


\section{Satisfaction Level of Old Age Allowance Receiving Elderly People}

\section{Objectives and Methodology}

This paper attempts to find out the factors associated with the satisfaction level of old age allowance received by the elderly people.

The study sites were selected together with people's representatives and officials of Kushma Municipality, Parbat constituting three wards $(5,7,11)$ representing urban setting and another three wards $(9,13,14)$ depicting the rural setting among the total of 14 wards in the municipality. The total population of the people aged 60 years and above in the municipality as per the record of the municipality office was 4257 comprising 2337 females and 1920 males. According to the National census 2011, the population of Kushma Municipality was 39600 with 21861 females and 17739 males. The average annual growth rate of population of the municipality was as low as 0.29 percent (CBS, 2012).

This study focuses on elderly people who have completed 60 years and above in Kushma municipality. The households having at least members aged 60 years and above were included in the study. Among the 14 wards of the municipality, six wards $(5,7,9,11,13$ and 14) were selected randomly among those with urban (5, 7 and 11) and rural $(9,13$ and 14) settings. The urban and rural settings were categorized based on the location within the premises of the headquarters and the outskirts of the municipality. The total elderly population of the selected wards was $1391^{1}$. The sample size was 136 among those who received elderly allowance from the municipality at the time of study. The primary data were collected through interviews using semi-structured questionnaires prepared on the basis of population based survey modules of the WHO (WHO, 2008; 2011) and preliminary field visits within the frames of the objectives of the study.

For qualitative information, two group discussions were conducted regarding the situation of satisfaction among the elderly people with use of the allowance received. Chi-square test was carried out to find the associated factors of satisfaction among the elderly people from the allowance received.

\section{Results and Discussion}

The socio-demographic status of the elderly under study focuses on age, caste/ethnicity and their literacy status (Table 1). Among the respondents, the proportion of males $(48.5 \%)$ is slightly smaller than that of females $(51.5 \%)$. Likewise, the age of the respondents ranges from 60 years to as high as 101 years with mean age of 76.70 years. More than a quarter (29.4\%) are between 70 and 75 , while one in every five is between 75 and 80 years, and 16.9 percent fall under the 80-85 years age group. Similarly, the caste/ethnic composition shows 39.7 percent Brahman, 25.7 percent Chhetri, 30.1 Dalit $^{2}$ and 4.4 percent Janajati ${ }^{3}$. More than two-third elderly are illiterate, while 70 percent of them are female and 30 percent are male. Nearly one-third elderly are either literate or have received a primary level of education.

\footnotetext{
${ }^{1}$ Allowance receiving beneficiary record, Fiscal Year 2020, Kushma Municipality

2 The Dalit category of the caste/ethnic group include Kami, Damai and Sarki in the study area.

${ }^{3}$ The Janajati category of the caste/ethnic group include Gurung, Magar and Newar in the study area.
} 
Satisfaction Level of Old Age Allowance Receiving Elderly People

Table 1. Socio-Demographic Features of the Elderly People

\begin{tabular}{|c|c|c|c|c|c|c|c|}
\hline \multirow{3}{*}{ Variables } & \multirow{3}{*}{ Categories } & \multicolumn{4}{|c|}{ Gender } & \multirow{2}{*}{\multicolumn{2}{|c|}{ Total }} \\
\hline & & \multicolumn{2}{|c|}{ Male } & \multicolumn{2}{|c|}{ Female } & & \\
\hline & & $\mathbf{N}$ & $\%$ & $\mathbf{N}$ & $\%$ & $\mathbf{N}$ & $\%$ \\
\hline \multirow{6}{*}{ Age } & $60-65$ & 7 & 5.1 & 7 & 5.1 & 14 & 10.3 \\
\hline & $65-70$ & 7 & 5.1 & 4 & 2.9 & 11 & 8.1 \\
\hline & $70-75$ & 17 & 12.5 & 23 & 16.9 & 40 & 29.4 \\
\hline & $75-80$ & 15 & 11.0 & 16 & 11.8 & 31 & 22.8 \\
\hline & $80-85$ & 11 & 8.1 & 12 & 8.8 & 23 & 16.9 \\
\hline & 85 and Above & 9 & 6.6 & 8 & 5.9 & 17 & 12.5 \\
\hline \multirow{4}{*}{$\begin{array}{l}\text { Caste/ } \\
\text { Ethnicity }\end{array}$} & Brahman & 19 & 14.0 & 35 & 25.7 & 54 & 39.7 \\
\hline & Chhetri & 18 & 13.2 & 17 & 12.5 & 35 & 25.7 \\
\hline & Dalit & 26 & 19.1 & 15 & 11.0 & 41 & 30.1 \\
\hline & Janajati & 3 & 2.2 & 3 & 2.2 & 6 & 4.4 \\
\hline \multirow{4}{*}{$\begin{array}{l}\text { Educational } \\
\text { Status }\end{array}$} & Illiterate & 28 & 20.6 & 64 & 47.1 & 92 & 67.6 \\
\hline & $\begin{array}{l}\text { Literate (Can } \\
\text { Read and Write) }\end{array}$ & 29 & 21.3 & 6 & 4.4 & 35 & 25.7 \\
\hline & Primary & 8 & 5.9 & 0 & 0.0 & 8 & 5.9 \\
\hline & Secondary & 1 & 0.7 & 0 & 0.0 & 1 & 0.7 \\
\hline Total & & 66 & 48.5 & 70 & 51.5 & 136 & 100.0 \\
\hline
\end{tabular}

Source: Field Survey, 2019

Receiving the allowances provided by the government is not so easy for the elderly people. As the allowance is provided through the bank account to be created as prescribed by the local bodies, they are supposed to do so and receive money. Reaching to the banks is not that easy for the elderly. The majority $(36.8 \%)$ of the respondents used public vehicles to the banks for receiving the allowances, followed by more than a third (36.0\%) of those had to walk on foot as there was no provision of public vehicles.

Table 2: Means of Transportation to Receive Old Age Allowance

\begin{tabular}{lcc}
\hline Process & Frequency & Percent \\
\hline By Public Vehicle & 50 & 36.8 \\
On Foot & 49 & 36.0 \\
Both (On Foot \& Public Vehicle) & 26 & 19.1 \\
By Families Private Vehicle & 11 & 8.1 \\
\hline Problems faced during receiving Old Age Allowance & \\
\hline Difficult to Walk & 37 & 27.2 \\
Long Distance & 33 & 24.3 \\
Crowded & 23 & 16.9 \\
Difficult Road & 11 & 8.1 \\
Others & 3 & 2.2
\end{tabular}


Satisfaction Level of Old Age Allowance Receiving Elderly People

\begin{tabular}{lcc}
\hline Process & Frequency & Percent \\
\hline By Public Vehicle & 50 & 36.8 \\
On Foot & 49 & 36.0 \\
Both (On Foot \& Public Vehicle) & 26 & 19.1 \\
By Families Private Vehicle & 11 & 8.1 \\
No any Problems & 29 & 21.3 \\
\hline Total & $\mathbf{1 3 6 . 0 0}$ & $\mathbf{1 0 0 . 0 0}$ \\
\hline
\end{tabular}

Source: Field Survey, 2019

Some of the elderly sometimes had to walk on foot to the nearest station to access public vehicles. Also, only a few respondents $(8.1 \%)$ used their families' or private vehicles. It is found that more than one in every four respondents reported that it was difficult to walk because of their physical problems. Similarly, about one fourth respondents reported that there is a long distance to go to the bank for an allowance received followed by 16.9 percent who faced crowding on the bank during the allowance received. Some of them $(8.1 \%)$ had problems with difficult roads. However, for 21.3 percent respondents there was no problem as such in receiving the allowance.

Table 3: Contribution of Old Age Allowances to the Life of Elder by Gender

\begin{tabular}{lccccccc}
\hline \multirow{2}{*}{ Area } & \multicolumn{3}{c}{ Sexes } & \multicolumn{3}{c}{ Total } \\
\cline { 2 - 5 } & \multicolumn{2}{c}{ Male } & \multicolumn{2}{c}{ Female } & & Number \\
\cline { 2 - 5 } & Number & $\mathbf{\%}$ & Number & $\mathbf{\%}$ & \% \\
\hline Personal expenses & 36 & 26.5 & 38 & 27.9 & 74 & 54.4 \\
Health and medication & 14 & 10.3 & 18 & 13.2 & 32 & 23.5 \\
Social Life & 12 & 8.8 & 12 & 8.8 & 24 & 17.6 \\
Others & 4 & 2.9 & 2 & 1.5 & 6 & 4.4 \\
\hline Total & $\mathbf{6 6}$ & $\mathbf{4 8 . 5}$ & $\mathbf{7 0}$ & $\mathbf{5 1 . 5}$ & $\mathbf{1 3 6}$ & $\mathbf{1 0 0}$ \\
\hline
\end{tabular}

Source: Field Survey, 2019

The majority of the elderly people utilize the allowances for their personal expenditures (54.4\%). In addition, their priority also goes with maintaining personal hygiene, seeing a doctor and purchasing medicines (23.5\%), while some of them made the most of such an amount for social life and contribution to support societal development. However, most of the elderly people reported during the group discussion, the amount of the allowance helped specially for their medical expenditure and daily foods and clothes.

Table 4. Effectiveness of Old Age Allowances by Caste/Ethnicity

\begin{tabular}{lcccccc}
\hline \multirow{2}{*}{ Caste/Ethnicity } & \multicolumn{3}{c}{ Effectiveness Status } & \multicolumn{2}{c}{ Total } \\
\cline { 2 - 5 } & \multicolumn{2}{c}{ Yes } & \multicolumn{2}{c}{ No } & & Number \\
\cline { 2 - 5 } & Number & \% & Number & \% & \% \\
\hline Brahman & 48 & 35.3 & 6 & 4.4 & 54 & 39.7 \\
Dalit & 36 & 26.5 & 5 & 3.7 & 41 & 30.1 \\
Chhetri & 34 & 25.0 & 1 & 0.7 & 35 & 25.7
\end{tabular}


Satisfaction Level of Old Age Allowance Receiving Elderly People

\begin{tabular}{lcccccc} 
Janajati & 6 & 4.4 & 0 & 0.0 & 6 & 4.4 \\
\hline Total & $\mathbf{1 2 4}$ & $\mathbf{9 1 . 2}$ & $\mathbf{1 2}$ & $\mathbf{8 . 8}$ & $\mathbf{1 3 6}$ & $\mathbf{1 0 0}$ \\
\hline
\end{tabular}

Source: Field Survey, 2019

It is found that, most of the respondents $(91.2 \%)$ by caste/ethnicity reported that old age allowance was and effective program for the ageing people for managing their daily life. Only a few respondents $(8.8 \%)$ reported that allowance is not effective for them because of the various causes like the amount received, distribution pattern, caste base discrimination and so on. To more than one third (35.3\%) Brahmins the allowance is effective followed by Dalits $(26.5 \%)$ and Chhetris (25\%).

Table 5. Satisfaction Level of Elderly on Old Age Allowance

\begin{tabular}{lcc}
\hline Satisfaction on OAA & Frequency & Percent \\
\hline Highly Satisfied & 48 & 35.3 \\
Somewhat Satisfied & 65 & 47.8 \\
Poorly Satisfied & 23 & 16.9 \\
\hline Total & $\mathbf{1 3 6 . 0 0}$ & $\mathbf{1 0 0 . 0 0}$ \\
\hline
\end{tabular}

Source: Field Survey, 2019

Overall, the level of satisfaction shows that four in every five is highly or somewhat satisfied and nearly 17 percent were poorly or not satisfied (Table 5). Nearly half of the respondents $(47.8 \%)$ were somewhat satisfied with the old age allowance program followed by more than one third respondents (35.3\%) were highly satisfied from the old age allowance program.

\section{How satisfied are the Elderly?}

There may be different variables associated with the satisfaction level of the elderly people on the old age allowance. Satisfaction level of the elderly is categorized into highly satisfied and fairly satisfied. The Chi Square results are analyzed as follows.

Table 6. Level of Satisfaction with Old Age Allowance

\begin{tabular}{|c|c|c|c|c|c|c|c|c|}
\hline \multirow{3}{*}{$\begin{array}{l}\text { Variable } \\
\text { Factors }\end{array}$} & \multirow{3}{*}{ Categories } & \multicolumn{7}{|c|}{$\begin{array}{l}\text { Satisfaction Level of the Respondent on Old Age } \\
\text { Allowance }\end{array}$} \\
\hline & & \multicolumn{2}{|c|}{$\begin{array}{c}\text { Highly } \\
\text { Satisfied }\end{array}$} & \multicolumn{2}{|c|}{ Fairly Satisfied } & \multicolumn{2}{|c|}{ Total } & $\begin{array}{c}\mathbf{P} \\
\text { Value }\end{array}$ \\
\hline & & $\mathbf{N}$ & $\%$ & $\mathbf{N}$ & $\%$ & $\mathbf{N}$ & $\%$ & \\
\hline \multirow{2}{*}{ Sex } & Male & 25 & 18.4 & 41 & 30.1 & 66 & 48.5 & \multirow{2}{*}{0.540} \\
\hline & Female & 23 & 16.9 & 47 & 34.6 & 70 & 51.5 & \\
\hline \multirow{3}{*}{ Age } & $60-70$ & 5 & 3.7 & 20 & 14.7 & 25 & 18.4 & \multirow{3}{*}{0.172} \\
\hline & $70-80$ & 29 & 21.3 & 42 & 30.9 & 71 & 52.2 & \\
\hline & $80 \&$ Above & 14 & 10.3 & 26 & 19.1 & 40 & 29.4 & \\
\hline \multirow{3}{*}{$\begin{array}{l}\text { Caste/ } \\
\text { Ethnicity }\end{array}$} & Brahman & 23 & 16.9 & 31 & 22.8 & 54 & 39.7 & \multirow{3}{*}{0.348} \\
\hline & Chhetri & 11 & 8.1 & 24 & 17.6 & 35 & 25.7 & \\
\hline & Dalit \&Janajati & 14 & 10.3 & 33 & 24.3 & 47 & 34.6 & \\
\hline Types of & Tin Roof & 8 & 5.96 & 36 & 26.5 & 44 & 32.4 & 0.015 \\
\hline
\end{tabular}




\section{Satisfaction Level of Old Age Allowance Receiving Elderly People}

\begin{tabular}{lllllllll} 
House & Stone Roof & 28 & 20.6 & 38 & 27.9 & 66 & 48.5 & \\
& Others & 12 & 8.86 & 14 & 10.3 & 26 & 19.1 & \\
\hline \multirow{2}{*}{$\begin{array}{l}\text { Education } \\
\text { al Status }\end{array}$} & Illiterate & 27 & 19.9 & 65 & 47.8 & 92 & 67.6 & \\
& Literate & 21 & 15.4 & 23 & 16.9 & 44 & 32.4 & $\mathbf{0 . 0 3 6}$ \\
& Total & $\mathbf{4 8}$ & $\mathbf{3 5 . 3}$ & $\mathbf{8 8}$ & $\mathbf{6 4 . 7}$ & $\mathbf{1 3 6}$ & $\mathbf{1 0 0}$ & \\
\hline
\end{tabular}

The Chi-Square Statistic P-value asymptotic significance (2-sided) is 0.015 and 0.036 for types of house and educational status. The result is significant at 5\% level of significance. The data shows that regardless of age, gender and caste/ethnicity of the elder people having received the allowances, the provision of the physical infrastructure and social development indicates a better level of satisfaction among the elderly. This clearly reflects the fact that there needs to be proper living arrangements and social development activities among the elderly people.

\section{Conclusion}

The elderly is the later stage of the human life cycle that brings physiological complications. An increase in medical costs, the need for personal support and insufficient funds to meet the needs are the main challenges the elderly people are facing in Nepal. The literacy rate of the elderly is very low. Elderly people have faced problems in receiving the allowances with accessibility factors such as distance, means of transport, and crowd. However, the old age allowance is helping the elderly to support their daily living, fulfil their personal and familial needs and help improve their health. So, the old age allowance program is effective for the elderly as the level of satisfaction is higher. The physical infrastructure and the socio-economic status have a positive association with the level of satisfaction among the elderly regarding the allowances received. A comprehensive in-depth study with nationally representative mixed methods research is sought to understand the real situation of elderly people in Nepal.

\section{Acknowledgements}

The article draws upon the data from an academic research study, which was supported by Ageing Nepal under Ageing Research Fellowship (ARF) 2019 research grants. The authors would like to acknowledge the support.

\section{References}

Babajanian, B. (2013) 'Tackling old age poverty and vulnerability: Social pensions in Asia. Poverty in Focus (25). International Policy Centre for Inclusive Growth http://www.ipc-undp.org/pub/IPCPovertyInFocus25.pdf

Badal, R. (2005). Social security system in Nepal. In Rimal, B., Upadhyay, U \& Khatiwada, P. (Eds.) Issue of the World of Work in Nepal. 163-169. https://www.gefont.org/assets/upload/downloads/Issue_of_the_World_of_Work_in Nepal.pdf

Begum, S. \& D. Wesumperuma. (2012). 'Old age allowance program in Bangladesh: Challenges and lessons'. In S.W. Handayani and B. Babajanian, eds. Social Protection for Older Persons: Social Pension in Asia. 187-213. Asian Development Bank.

Bhatta, R. (2009). Social and Health Status of Elderly Population in Far-Western Region. 


\section{Satisfaction Level of Old Age Allowance Receiving Elderly People}

Submitted to Nepal Health Research Council, Kathmandu, Nepal. http://library.nhrc.gov.np:8080/nhrc/bitstream/handle/123456789/42/558.pdf

CBS (2012). National Population and Housing Census 2011. https://unstats.un.org/unsd/demographic-social/census/documents/Nepal/NepalCensus-2011-Vol1.pdf

Dhungana, G. P., Sapkota, M., \& Bista, B. (2020, Jun). Older people's satisfaction with and utilisation patterns of the Old Age Allowance in Nepal. Australasian Journal on Ageing, 39(2), 178-184. https://doi.org/10.1111/ajag.12729

Ghimire, S., Baral, B. K., Karmacharya, I., Callahan, K., \& Mishra, S. R. (2018, Jun 7). Life satisfaction among elderly patients in Nepal: Associations with nutritional and mental well-being. Health and Quality of Life Outcomes, 16(1), 118. https://doi.org/10.1186/s12955-018-0947-2

Grossman, S. \& Lange, J. (2006). Theories of aging as basis for assessment. MEDSURG Nursing, 15(2), 77-83.

Gupta, A. A., Lall, A. K., Das, A., Saurav, A., Nandan, A., Shah, D., Agrahari, A., \& Yadav, D. K. (2016, Oct-Dec). Health and socioeconomic status of the elderly people living in hilly areas of Pakhribas, Kosi Zone, Nepal. Indian Journal of Community Medicine, 41(4), 273-279. https://doi.org/10.4103/0970-0218.193333

Khattri, J. B., Godar, S. T., Subedi, A., \& Tirkey, S. (2020, May 30). Psychiatric morbidities of elderly out-patients attending various Outreach Clinics in Gandaki Province of Nepal: A Descriptive cross-sectional study. Journal of Nepal Medical Association, 58 (225), 318-323. https://doi.org/10.31729/jnma.4996

Kshetri, D. B., Smith, C. S., \& Khadka, M. (2012, Sep). Social care and support for elderly men and women in an urban and a rural area of Nepal. Aging Male, 15(3), 148-152. https://doi.org/10.3109/13685538.2012.666920

Kshetri, D. B., \& Smith, W. C. (2011, Jun). Self-reported health problems, health care utilisation and unmet health care needs of elderly men and women in an urban municipality and a rural area of Bhaktapur district of Nepal. Aging Male, 14(2), 127-131. https://doi.org/10.3109/13685538.2010.502272

Limbu, A. (2012). Age Structure Transition and Senior Citizens in Nepal: The impending Challenges. Alliance for Social Dialogue. http://asd.org.np/wpcontent/uploads/2015/03/age_structure_transition_and_senior_citizens_in_nepal0.p $\underline{\mathrm{df}}$

Malakar, I., \& Chalise, H. (2019). Perception of elderly towards social security allowance in Nepal. South Asian Journal of Social Studies and Economics, 2(4), 1-9. https://doi.org/10.9734/sajsse/2018/v2i430008

Maslow, A. H. (1943). A Theory of human motivation. Psychological Review, 50(4), 37096. https://doi.org/10.1037/h0054346

Maslow, A. H. (1953). Motivation and personality. Harper and Row. 


\section{Satisfaction Level of Old Age Allowance Receiving Elderly People}

National Planning Commission [NPC] (2012). Assessment of social security allowance program in Nepal. https://www.npc.gov.np/images/category/Assessment-of-SocialSecurity-Allowance-Program-in-Nepal.pdf

Poudel, N. (2005). Problems of Elderly Population. http://globalag.igc.org/elderrights/world/2007/being.htm

Nepal Law Commission (2006), Senior Citizen's Act. https://www.lawcommission.gov.np/en/archives/category/documents/prevailinglaw/statutes-acts/senior-citizens-act-2063-2006

Shrestha, H. S. \& Satyal, V. R. (2003). Social Security for the elderly in Nepal. Institute for Integrated Development Studies (IIDS).

Shrestha, L. (2012). Geriatric health in Nepal: Concerns and experience. Nepal Med College Journal 2012; 15(2), 144-148. https://www.nmcth.edu/images/gallery/Review\%20Article/oVWgaL\%20Shrestha.p $\underline{\mathrm{df}}$

Subedi, B. P. (1996). The Geo-demographic context of population ageing in Nepal. CNAS Journal, 23(2), 423-439. http://himalaya.socanth.cam.ac.uk/collections/journals/contributions/pdf/CNAS_23 02 04.pdf

Thapa, P., Chakraborty, P. K., Khattri, J. B., Ramesh, K., \& Sharma, B. (2014, Jul-Dec). Psychiatric morbidity in elderly patients attending OPD of tertiary care centre in western region of Nepal. Industrial Psychiatry Journal, 23(2), 101-104. https://doi.org/10.4103/0972-6748.151673

Thapa, R., Khanal, S., Tan, H. S., Thapa, S. S., \& van Rens, G. (2020). Prevalence, pattern and risk factors of retinal diseases among an elderly population in Nepal: The Bhaktapur retina study. Clinical Ophthalmology, 14, 2109-2118. https://doi.org/10.2147/OPTH.S262131

United Nations Department of Economic and Social Affairs, Population Division [UNDESA/PD] (2020). World population ageing 2020 highlights: Living arrangements of older persons (ST/ESA/SER.A/451). https://www.un.org/development/desa/pd/sites/www.un.org.development.desa.pd/fil es/undesa pd-2020 world population ageing highlights.pdf

United Nations Population Fund [UNFPA] (2012). Ageing in the twenty-first century: A celebration and a challenge. https://www.unfpa.org/publications/ageing-twentyfirst-century

Wallace, D. J. (1997). The Biology of aging: An overview of aging. Journal of American Magazine, Geriatric Society.

World Health Organization [WHO] (5 February, 2018). World health organization. Ageing and health key facts. https://www.who.int/news-room/fact-sheets/detail/ageing-andhealth 
Satisfaction Level of Old Age Allowance Receiving Elderly People

WHO (2011). Global health and ageing.

https://www.who.int/ageing/publications/global health.pdf.

WHO (2008). Age-friendly primary health care (PHC) centres toolkit.

https://www.who.int/ageing/publications/AF_PHC_Centretoolkit.pdf.

WHO (2002). Definition of an older or elderly person, Health statistics and information systems, WHO. http://www.who.int/healthinfo/ survey/ageingdefnolder/en/

Yadav, R. K. (2012). Ageing population in Nepal: Challenges and management. Vol. 2, No. 1, 2012, 48-53. https://www.nepjol.info/index.php/AV/article/view/8287. 